\title{
Influence of caprine arthritis encephalitis on milk production and quality along the lactation curve in primiparous dairy goats
}

\section{Influência da artrite encefalite caprina na produção e qualidade do leite ao longo da curva de lactação em cabras leiteiras primíparas}

\author{
Julcimara Alves Araujo'; Erica Beatriz Schultz²*; Magna Coroa Lima3; Rodrigo \\ Vasconcelos de Oliveira2; Marcelo Teixeira Rodrigues ${ }^{4}$; Lisia Castro Krebs ${ }^{5}$; \\ Raquel Silva de Oliveira ${ }^{1}$; Priscila Bernardo de Andrade ${ }^{6}$
}

\section{Highlights}

Caprine arthritis encephalitis does not affect primiparous dairy goat performance.

The milk composition is similar between seropositive and seronegative goats.

Seronegative goats have higher production than seropositive goats at peak lactation.

\begin{abstract}
The aim of this study was to examine the influence of caprine arthritis encephalitis (CAE) on the production of milk and its components (protein, fat and total solids) along the lactation curve of primiparous goats. The study was developed using a database from the years 2014 to 2018. Sixty-one animals were subjected to the serological test for CAE, whose result indicated that 42 were seropositive and 19 seronegative, and milk production and quality data were compiled. To adjust the curve for production of milk, fat, protein and total solids during lactation, the following nonlinear model developed by Wood (1967) was used: $Y=a t^{b} e^{-c t}$, where $Y$ represents the observations of milk, fat, protein or total solid production at time $t ; a$ is the parameter associated with the initial production; $b$ is the parameter associated with the rate of rise in production until the peak; $c$ is the parameter associated with the rate of decline of the lactation curve; and

1 Undergraduate of Animal Science, Universidade Federal Rural do Rio de Janeiro, UFRRJ, Seropédica, RJ, Brazil. E-mail alvesaraujo.ja@gmail.com; raquel.oliveiraasilva@gmail.com

2 Profs. Drs. of Animal Science, UFRRJ, Seropédica, RJ, Brazil. E-mail: ericabeatrizschultz@gmail.com; oliveirarvetal@ gmail.com

${ }^{3}$ Profa Dra of Veterinay, Universidade de Viçosa, UNIVIÇOSA, Viçosa, MG, Brazil. E-mail: magnaveterinaria@yahoo. com.br

${ }^{4}$ Prof. Dr. of Animal Science, Universidade Federal de Viçosa, UFV, MG, Brazil. E-mail: mtrodri@ufv.br

${ }^{5}$ Graduate Student of Master in Animal Science, UFRRJ, Seropédica, RJ, Brazil. E-mail: lisiack27@hotmail.com

${ }^{6}$ Graduate Student of Master in Animal Science, Universidade Federal do Mato Grosso do Sul, UFMS, MS, Brazil. E-mail: pri.zootecnia.ufrrj@gmail.com

* Author for correspondence
\end{abstract}

Received: Aug. 23, 2020 - Approved: May 17, 2021 
$t$ is the representative time of the day in milk. The parameters were compared by the confidence interval considering $95 \%$ probability. Peak production was calculated using the following formula: $a(b / c)^{b} e^{-b}$. There was no statistical difference $(p>0.05$ ) between seropositive and seronegative primiparous goats for initial production and the rates of rise and decline of the parameters of milk, fat, protein and total solid production. However, at their peak, these variables were 26, 27, 23 and 23\% higher, respectively, in the seronegative goats than in their seropositive counterparts. In conclusion, CAE does not affect milk production or the production of fat, protein and total solids along the lactation curve, but seropositive goats produce less milk and respective components at the peak of the lactation curve than seronegative goats.

Key words: Nonlinear models. Performance. Small ruminants.

\section{Resumo}

Objetivou-se avaliar a influência da artrite encefalite caprina (CAE) sobre a produção leiteira e seus constituintes (proteína, gordura e sólidos totais) ao longo da curva de lactação de cabras primíparas. O estudo foi realizado a partir do banco de dados dos anos de 2014 a 2018. Foram utilizados um total de 61 animais, todos submetidos ao teste de sorologia para CAE, sendo 42 cabras soropositivas e 19 soronegativas, e os dados foram compilados de produção e qualidade do leite. Para o ajuste da curva para a produção de leite, gordura, proteína e sólidos totais ao longo da lactação foi utilizado o modelo não linear de Wood (1967): $Y=a t^{b} e^{-c t}$, no qual: $Y$ representa as observações de produção de leite, gordura, proteína ou sólidos totais no tempo $t$, $a$ é o parâmetro associado à produção inicial, $b$ é o parâmetro associado à taxa de ascensão da produção até o pico, c é o parâmetro associado à taxa declínio da curva de lactação e $t$ é o tempo representativo do dia em lactação. Os parâmetros foram comparados pelo intervalo de confiança considerando $95 \%$ de probabilidade. A produção no pico foi calculada pela fórmula: $a(b / c)^{b} e^{-b}$. Não houve diferença estatística $(p>0,05)$ entre cabras primíparas soropositivas e soronegativas para a produção inicial, taxa de ascensão e taxa de declínio dos parâmetros para a produção de leite, de gordura, de proteína e de sólidos totais. Porém a produção no pico das variáveis em cabras soronegativas foi de $26 \%$, 27\%, 23\% e 23\%, respectivamente, mais altas que em soropositivas. Conclui-se que a CAE não afeta a produção leiteira, bem como a produção de gordura, proteína e sólidos totais ao longo da curva de lactação, entretanto cabras soropositivas têm menor produção de leite e de seus componentes no pico da curva de lactação em relação às soronegativas.

Palavras-chave: Desempenho. Modelo não linear. Pequenos ruminantes.

\section{Introduction}

Caprine arthritis encephalitis (CAE) is a cosmopolitan disease caused by a virus of the genus Lentivirus. It is classified into five genotypes, with $A$ and $B$ being widely distributed and $C, D$ and $E$ not as widespread (Michiels et al., 2018). Frequent symptoms include arthritis, pneumonia, leukoencephalomyelitis, muscle weakness, tremors and mastitis. For this reason, studies have focused on its seroprevalence and implementation of control and animal selection measures (Michiels et al., 2018; Venturino et al., 2019; Schultz et al., 2020).

The CAE virus is transmitted mainly via colostrum and milk from infected animals and through contact with secretions such as the saliva and semen of positive animals 
(Souza et al., 2013; Hasegawa et al., 2017), and hence the importance of early diagnosis, isolation and disposal of infected animals as a way of preventing vertical and horizontal transmission in the herd (Konishi, Nagura, Takei, \& Fujita, 2011). According to Alcindo et al. (2020), who evaluated the effectiveness of adopting control measures in dairy cattle with confirmed occurrence of CAE and its impacts on the incidence of the disease, as the animals grow older, even if some of the recommended control protocols are established, the likelihood of their remaining seronegative decreases over time. Thus, early identification, through periodic tests, and the separation of these animals from the herd can contribute to reducing future losses. However, further studies are required on the means of transmission, as lentivirus infection has a high incubation period and high pathogenicity, and there are no vaccines against it.

Research shows that among the losses caused by this disease, seropositive animals exhibit a decline in milk production and quality, with an increase in somatic cell counts (Leitner et al., 2010; Martínez-Navalón et al., 2013). However, conflicting results such as those published by Greenwood (1995); Nord and Adnoy (1997); Turin et al. (2005) and Kaba, Strzałkowska, Jóźwik, Krzyżewski and Bagnicka (2012) have shown that in the first lactation, there is no significant difference in milk production or quality between animals seropositive and seronegative for CAE. For this reason, there is a need to elucidate these contradictions regarding the impact of CAE on the productivity of young animals as well as to assist producers in making decisions about the maintenance of these animals in the herd.

To analyze the effects of CAE on milk production and quality, the approach by non-linear models is robust, as it describes production throughout lactation together with the possibility of biological interpretation of its parameters. According to Arnal, RobertGranie and Larroque (2018), lactation curves are important tools for the study of individual or herd production, as they allow monitoring that helps with management adjustments. Of the models most used to describe lactation curves, that which most stands out is the nonlinear model developed by Wood (1967), which allows estimating the time necessary to reach that production and lactation persistency through the parameters of initial production, rate of rise and rate of decline, in addition to basic characteristics of the curve such as maximum milk production.

Thus, we hypothesize that CAE affects the production milk of and its constituents along the lactation curve of primiparous dairy goats. Therefore, the aim of this study was to investigate the influence of CAE on milk production and its components (protein, fat and total solids) along the lactation curve of primiparous dairy goats.

\section{Material and Methods}

The study was carried out in the Goat Farming Section of the Department of Animal Science at the Federal University of Viçosa, after approval by the Ethics Committee of the Viçosa University Center (approval no. 265.2018.01.01.15.03).

The animals were housed in collective $4 \mathrm{~m} \times 6 \mathrm{~m}$ stalls, where they were divided by genetic merit of production and days in milk. All the goats used were kept in the same environment and originated from the same herd, in an intensive feedlot system. The 
feed was the same for all animals throughout the entire period, which was balanced with an average of $60 \%$ maize silage and $40 \%$ concentrate composed of a mixture of ground maize, soybean meal, urea with ammonium sulfate, sodium bicarbonate, sodium monensin and a mineral mixture to meet nutritional requirements adjusted during lactation, following the National Research Council [NRC] (2007). Table 1 shows the feed composition.

\section{Table 1}

\section{Composition of the feed ingredients used in the diet fed to the dairy goats}

\begin{tabular}{|c|c|c|c|}
\hline Ingredient & \multicolumn{3}{|c|}{ Proportion $\left(\mathrm{g} \mathrm{kg}^{-1}\right)$} \\
\hline Maize silage & \multicolumn{3}{|c|}{600.0} \\
\hline Maize & \multicolumn{3}{|c|}{270.2} \\
\hline Soybean meal & \multicolumn{3}{|c|}{110.0} \\
\hline Mineral salt & \multicolumn{3}{|c|}{6.8} \\
\hline Dicalcium phosphate & \multicolumn{3}{|c|}{3.6} \\
\hline Calcium & \multicolumn{3}{|c|}{3.6} \\
\hline Urea with ammonium sulfate & \multicolumn{3}{|c|}{3.2} \\
\hline Sodium bicarbonate & \multicolumn{3}{|c|}{2.4} \\
\hline Sodium monensin & \multicolumn{3}{|c|}{0.08} \\
\hline Composition $\left(\mathrm{g} \mathrm{kg}^{-1}\right)$ & Concentrate & Silage & Total diet \\
\hline Dry matter & 890.0 & 263.7 & 514.2 \\
\hline Crude protein & 148.0 & 60.0 & 95.2 \\
\hline Ether extract & 38.0 & 23.3 & 29.2 \\
\hline Neutral detergent fiber & 201.0 & 594.2 & 436.9 \\
\hline
\end{tabular}

The information used in the study was collected from 2014 to 2018 . As the goats were included in the study, that is, before the start of milk testing, serological tests for CAE were performed and clinical signs of the disease such as swelling of the joints, tremors and decubitus were monitored. Blood samples were collected by jugular vein puncture in tubes without anticoagulant. After collection, the samples were immediately centrifuged at $2,700 \times \mathrm{g}$ for $20 \mathrm{~min}$. Then, plasma samples were taken from each animal for immunodiffusion on agar gel using the Biovetech ${ }^{\circledR}$ CAE diagnostic kit.
After the test results were checked, data on milk production and quality of 61 primiparous Saanen and Alpine chamois goats at an average age of $22 \pm 7$ months were compiled, with 42 seropositive and 19 seronegative animals. The selected animals had at least four measurements of milk production and quality along the lactation curve.

Milk production was measured weekly in individual milk testing, at 06h00 and 14h00. Before the amount of milk produced per animal was measured, the strip-cut test and pre-dipping with lodophor $^{\circledR}$ solution were performed. 
The animals were milked mechanically and the amount of milk was measured using a MiniTru-Teste ${ }^{\circledR}$ sampler with a maximum capacity of $10 \mathrm{~L}$ and accuracy of $100 \mathrm{~mL}$. After milking, all animals went through the postdipping procedure with Teto-in ${ }^{\circledR}$ solution.

For the composition of milk, collections were carried out monthly after the test day in appropriate jars containing Bronopol $^{\circledR}$ (2-bromo-2-nitropropane-1,3-diol). The aliquots were representative of the two milking events, and readings were taken using the MilkoScan ${ }^{\mathrm{TM} M i n o r}$ instrument (Foss, Denmark) to determine the percentages of fat, protein and total solids.

The experimental design was as shown below:

$$
Y_{i j}=\mu+\text { Year }_{i}+e_{i j} \text {, }
$$

where $Y$ is the observation, $\mu$ is the overall mean, Year is the effect of the year of collection and $e$ is the random error.

Wood's (1967) nonlinear model was fitted for the production of milk, fat, protein and solids during lactation, as follows: $Y=a t^{b} e^{-c t}$, where $Y$ represents the observed production of milk, fat, protein or total solids at time $t$; a is the parameter associated with the initial production; $b$ is the parameter associated with the rate of rise in production to the peak; $c$ is the parameter associated with the rate of decline of the lactation curve; and $t$ is the representative time of the day in milk.

To fit the model, the nlme function of the nlme package was used, according to Pinheiro and Bates (2006), in which all parameters $(a, b, c)$ were considered to have a fixed serology effect for CAE. In conjunction with the fixed effects, different combinations of parameters were tested for the random effects and covariance structures (unstructured, composite and autoregressive symmetry, with and without correlation). The model was selected according to the corrected Akaike information criterion (AICC).

After choosing the model for lactation persistency, the values of parameters $a, b$ and c were obtained for the goats seropositive and seronegative for CAE. The parameters were compared by the confidence interval considering $95 \%$ probability. Peak production was calculated using the following formula: $a(b / c)^{b} e^{-b}$, with descriptive comparisons. All analyses were performed in $\mathrm{R}^{\circledR}$ software.

\section{Results and Discussion}

Caprine arthritis encephalitis has already been described in several countries on all continents, with its highest prevalence (above 65\%) being in countries with intensive farming, such as Italy, Canada and France, and lower rates (below 10\%) occurring in countries with greater control over the herd or which import animals, such as New Zealand and Peru, respectively (Tabet, Hosri, \& Abi-Rizk, 2015; Cirone et al., 2019).

In Brazil, de Sousa et al. (2019) described a rate of $6.2 \%$ infected animals in the northeast region, with the incidence of the disease occurring in $11.2 \%$ of the 251 studied properties. In the region of Rio Grande do Norte, Damasceno et al. (2020) described $3.9 \%$ of infected animals in $42.6 \%$ of herds. The fact that extensive farms have a lower disease rate may be related to the few tests performed due to the cost of exams and the animals' hardiness. As reported by Alcindo et al. (2020), the economic impact must be considered in the establishment of preventive measures 
such as testing the herd and separating seropositive animals, demonstrating the worldwide and national importance of studies related to the disease.

As regards the parameters of the milk production curve, there was no difference $(p>0.05)$ between seropositive and seronegative goats for the initial milk production (a). Likewise, there was no statistical difference for parameters $b$ and $c$ ( $p>0.05$ ) (Table 2).

Table 2

Comparison of milk production parameters along the lactation curve in primiparous goats of the Saanen and Alpine chamois breeds seronegative and seropositive for caprine arthritis encephalitis (CAE)

$\begin{array}{cccccc}\text { CAE test } & \text { Parameter } & \text { Mean } & \text { SEM } & \begin{array}{c}\text { Lower } \\ \text { (Cl: } 95 \%)\end{array} & \begin{array}{c}\text { Upper } \\ \text { (Cl: 95\%) }\end{array} \\ \text { Negative } & a & 1.068 & 0.371 & 0.697 & 1.439 \\ \text { Positive } & & 1.094 & 0.230 & 0.864 & 1.324 \\ \text { Negative } & b & 0.292 & 0.154 & 0.138 & 0.446 \\ \text { Positive } & & 0.165 & 0.093 & 0.072 & 0.257 \\ \text { Negative } & c & 0.007 & 0.004 & 0.003 & 0.011 \\ \text { Positive } & & 0.003 & 0.002 & 0.001 & 0.005 \\ \text { Negative } & P P & 2.389 & & & \\ \text { Positive } & & 1.764 & & & \end{array}$

a: initial milk production $(\mathrm{kg}) ; b$ : rate of rise of the production curve; $c$ : rate of decline of the production curve; PP: peak of production. SEM: standard error of the mean; Cl: confidence interval.

The non-significance of the parameters shows that CAE did not affect milk production along the entire lactation curve, confirming the reports of Nord and Adnoy (1997) and Kaba et al. (2012), that CAE does not influence the average milk production of primiparous animals.

Martínez-Navalón et al. (2013) suggested that productive loss in seropositive goats takes place gradually over the course of lactations, with significantly lower values occurring from the third lactation onwards, when compared with seronegative ones in the same lactation order, given the chronicity and progressive worsening of the disease.
In addition, the disease persists and the animals exhibit increased susceptibility to other diseases due to the impact of CAE on their immune system, as demonstrated by Greenwood (1995), with younger goats normally being asymptomatic.

Parameters $b$ and $c$ are related to the period necessary to reach maximum production and lactation persistency, which is defined as the animal's ability to maintain milk production after reaching the peak of lactation (Bouallegue \& M'Hamdi, 2019). Parameter c is inversely proportional to the time interval in which the animal maintains production close after peak lactation. 
The lack of significance for milk production parameters $b$ and $c$ between seropositive and seronegative goats is also, according to Greenwood (1995), an indication that young animals are not as severely affected by the disease as older ones, precisely because of the long period of development of the disease.

The milk production values of 1.081 , 0.228 and 0.005 encountered for parameters $a, b$ and $c$, respectively, are within the range described by Siqueira et al. (2017) for the Saanen and Alpine chamois breeds, with minimum and maximum values of 0.30 and 4.49 for parameter $a ; 0.00$ and 0.97 for $b$; and 0.00 and 0.05 for $c$.

The same response pattern in milk production occurred for milk quality, as shown in Tables 3 and 4, where the initial production $(a)$ and the rates of rise (b) and decline (c) of fat and protein did not differ between the animals with or without the disease $(p>0.05)$.

\section{Table 3}

Comparison of the parameters of fat production along the lactation curve in primiparous goats of the Saanen and Alpine chamois breeds seronegative and seropositive for caprine arthritis encephalitis (CAE)

$\begin{array}{cccccc}\text { Treatment } & \text { Parameter } & \text { Mean } & \text { SEM } & \begin{array}{c}\text { Lower } \\ \text { (Cl: 95\%) }\end{array} & \begin{array}{c}\text { Upper } \\ \text { (Cl: 95\%) }\end{array} \\ \text { Negative } & a & 0.0492 & 0.0177 & 0.0315 & 0.0669 \\ \text { Positive } & & 0.0506 & 0.0110 & 0.0396 & 0.0616 \\ \text { Negative } & b & 0.2052 & 0.1571 & 0.0481 & 0.3623 \\ \text { Positive } & & 0.0849 & 0.0945 & -0.0096 & 0.1794 \\ \text { Negative } & c & 0.0046 & 0.0037 & 0.0009 & 0.0083 \\ \text { Positive } & & 0.0019 & 0.0021 & -0.0002 & 0.0041 \\ \text { Negative } & P P & 0.0874 & & & \\ \text { Positive } & & 0.0641 & & & \end{array}$

$a$ : initial fat production $(\mathrm{kg}) ; b$ : rate of rise of the production curve; $c$ : rate of decline of the production curve; $P P$ : peak of production. SEM: standard error of the mean; Cl: confidence interval. 
Table 4

Comparison of the parameters of protein production along the lactation curve in primiparous goats of the Saanen and Alpine chamois breeds seronegative and seropositive for caprine arthritis encephalitis (CAE)

$\begin{array}{cccccc}\text { Treatment } & \text { Parameter } & \text { Mean } & \text { SEM } & \begin{array}{c}\text { Lower } \\ \text { (Cl: 95\%) }\end{array} & \begin{array}{c}\text { Upper } \\ (\mathrm{Cl:} 95 \%)\end{array} \\ \text { Negative } & a & 0.0362 & 0.0127 & 0.0234 & 0.0489 \\ \text { Positive } & & 0.0374 & 0.0079 & 0.0295 & 0.0454 \\ \text { Negative } & b & 0.2319 & 0.1547 & 0.0772 & 0.3866 \\ \text { Positive } & & 0.1174 & 0.0925 & 0.0248 & 0.2099 \\ \text { Negative } & c & 0.0053 & 0.0038 & 0.0016 & 0.0091 \\ \text { Positive } & & 0.0023 & 0.0022 & 0.0001 & 0.0045 \\ \text { Negative } & P P & 0.0688 & & & \\ \text { Positive } & & 0.0528 & & & \end{array}$

a: initial protein production $(\mathrm{kg}) ; b$ : rate of rise of the production curve; $c$ : rate of decline of the production curve; PP: peak of production. SEM: standard error of the mean; Cl: confidence interval.

Fat is the milk component that most oscillates with genetic, health and nutritional effects, but it did not show significant differences between the groups of animals studied. The presented values may be a result of the dairy aptitude of the breeds used, the feed provided and their age, since the symptoms caused by CAE worsen over time, suggesting that older animals are the most affected (Greenwood, 1995; Kaba et al., 2012).

There was no significant difference for initial fat production (a), contrary to the reports of Turin et al. (2005), who found higher fat values in primiparous goats seropositive for CAE.

Caprine arthritis encephalitis did not influence protein production along the lactation curve (Table 4), and thus there possibly was no change in the protein content or the beneficial aspect of milk. The same results for protein production were observed by Nord and Adnoy (1997), who did not demonstrate significantly different values between primiparous healthy and diseased goats.

Total solids represents the sum of all components of milk, namely fat, protein, lactose and minerals. Therefore, like fat and protein, this variable did not show significant values for the curve parameters throughout the lactation period ( $p>0.05$ ) (Table 5). The milk components are balanced with each other, denoting a stability that allows analyses as well as provides indications in case something is impairing the milk production by the goats. 


\section{Table 5}

Comparison of the parameters of total solid production along the lactation curve in primiparous goats of the Saanen and Alpine chamois breeds seronegative and seropositive for caprine arthritis encephalitis (CAE)

\begin{tabular}{cccccc} 
Treatment & Parameter & Mean & SEM & $\begin{array}{c}\text { Lower } \\
\text { (Cl: } 95 \%)\end{array}$ & $\begin{array}{c}\text { Upper } \\
\text { (Cl: } 95 \%)\end{array}$ \\
\hline Negative & $a$ & 0.1096 & 0.0430 & 0.0666 & 0.1526 \\
Positive & & 0.1377 & 0.0309 & 0.1069 & 0.1686 \\
\hline Negative & $b$ & 0.3229 & 0.1740 & 0.1488 & 0.4969 \\
\hline Positive & & 0.1439 & 0.1010 & 0.0429 & 0.2449 \\
Negative & $c$ & 0.0066 & 0.0050 & 0.0016 & 0.0116 \\
Positive & & 0.0025 & 0.0029 & -0.0005 & 0.0054 \\
Negative & $P P$ & 0.279 & & & \\
Positive & & 0.214 & & &
\end{tabular}

a: initial total solid production $(\mathrm{kg}) ; b$ : rate of rise of the production curve; $c$ : rate of decline of the production curve; $P P$ : peak of production. SEM: standard error of the mean; Cl: confidence interval.

Lucey, Otter and Horne (2017) demonstrated the advances in the study of milk components, reminding that protein accounts for about 3 to $4.5 \%$ of the total; fat, for approximately 3 to $4 \%$, whereas total solids are characterized as a sum of fat, protein, lactose and minerals, corresponding to about 12 to $18 \%$ of the total. In this way, the sum of fat and protein (about $8 \%$ of the total components of milk) contributes a proportion greater than $50 \%$ of total solids, which possibly resulted in no significant differences in total solid production between healthy goats and goats seropositive for CAE.

The description of production at the peak of the lactation curve indicates a pattern for the variables of milk, fat, protein and total solid production, which were $26 \%, 27 \%, 23 \%$ and $23 \%$ higher in the seronegative animals, respectively (Tables 1 to 5). Based on the production values at the peak of lactation, we have a practical indication for the separation of seropositive animals. This is because the period from the first third of lactation to the peak of production was marked by a negative energy balance, with rising production and a gradual restoration of the dry matter intake capacity (Silva, Assis Silva, Alcântara, \& Carvalho, 2019). With the metabolic challenge in the first third of lactation, the seronegative goats managed to maintain greater production at peak lactation in comparison to the seropositive animals.

The fact that primiparous goats seropositive for CAE do not show significant differences in milk production and quality may explain the prevalence of the disease in the production systems, since there is no way to perceive its presence based only on the measurement of production. This further evidences the need for periodic examinations in herds, which is not always done. Additionally, other factors corroborate its permanence and the consequent infection of healthy animals, such as lack of sanitary control. 
Despite the lack of significant differences in milk production and composition, no disease has positive effects on the herd. In animals with successive pregnancies, breast lesions, characterized by hyperplasia of the lymphoid follicles and subsequent fibrosis, become significantly more severe (Piva et al., 2017). Therefore, it is important to adopt prophylactic management and diagnostic measures aimed at eradicating the disease from the herd, e.g., adequate hygiene of the milking equipment, isolation of the contaminated animals and feeding the newborns with colostrum that has undergone thermal control (Rodrigues et al., 2018).

This is the first study to reveal the effects of CAE on milk production and quality throughout lactation under the approach of a nonlinear model. This model has shown satisfactory results in terms of production of milk and its components for peak production and their rate of decline during lactation, indicating the productivity of the adopted system-collectively or individually. In addition, it allows a biological interpretation of the curve parameters (Melo et al., 2011) and helps to evaluate productive impacts during the lactation of animals when affected by some disease, as described by Lopes et al. (2016).

\section{Conclusion}

There is no difference in milk production and composition between primiparous goats seronegative and seropositive for caprine arthritis and encephalitis. In this condition, non-suspicion of the occurrence of this disease can contribute to its prevalence in the herd.

\section{References}

Alcindo, J. F., Simões, S. V. D., Pinheiro, R. R., Peixoto, R., Andioli, A., Schultz, E. B., \& Feitosa, F. L. F. (2020). Efficacy of measures to control caprine arthritisencephalitis in dairy herds with high clinical and serological prevalence. Semina: Ciências Agrárias, 41(5 Supl. 1), 2179-2194. doi: 10.5433/1679-0359.20 20v41n5Supl1p2179

Arnal, M., Robert-Granie, C., \& Larroque, H. (2018). Diversity of dairy goat lactation curves in France. Journal of Dairy Science, 101(12), 11040-11051. doi: 10.3168/jds. 2018-14980

Bouallegue, M., \& M'Hamdi, N. (2019). Mathematical modeling of lactation curves: a review of parametric models. In Intechopen Limited (Ed.), Lactation in farm animals-biology, physiological basis, nutritional requirements, and modelization. (21. 13-14). London: United Kingdom.

Cirone, F., Maggiolino, A., Cirilli, M., Sposato, A., Palo, P. de, Ciappetta, G., \& Pratelli, A. (2019). Small ruminant lentiviruses in goats in southern Italy: Serological evidence, risk factors and implementation of control programs. Veterinary Microbiology, 228(1), 143-146. doi: 10.10 16/j.vetmic.2018.11.023

Damasceno, E. M., Pinheiro, R. R., Andrioli, A., Alves, F. S. F., Lima, A. M. C., Peixoto, R. M.,... Brandão, I. S. (2020). Seroprevalence and associated risk factors of Mycoplasma agalactiae and investigation of coinfection with the caprine lentivirus in Rio Grande do Norte, Brazil. Tropical Animal Health and Production, 52(1), 1-7. doi: 10.1007/ s11250-020-02234-5 
Greenwood, P. L. (1995). Effects of caprine arthritis-encephalitis virus on productivity and health of dairy goats in New South Wales, Australia. Preventive Veterinary Medicine, 22(1-2), 71-87. doi: 10.1016/01 67-5877(94)00399-4

Hasegawa, M. Y., Lara, M. do C. C. S. H., Gaeta, N. C., Marques, J. A., Ribeiro, B. L. M., Rossi, R. S.,... Gregory, L. (2017). Transmissibilidade de Lentivírus de pequenos ruminantes para cabritos e cabras adultas por meio de sêmen infectado experimentalmente. Pesquisa Veterinária Brasileira, 37(8), 805-812. doi: 10.1590/s0100-736x20170 00800005

Kaba, J., Strzałkowska, N., Jóźwik, A., Krzyżewski, J., \& Bagnicka, E. (2012). Twelve-year cohort study on the influence of caprine arthritis-encephalitis virus infection on milk yield and composition. Journal of Dairy Science, 95(4), 16171622. doi: 10.3168/jds.2011-4680

Konishi, M., Nagura, Y., Takei, N., \& Fujita, M. (2011). Combined eradication strategy for CAE in a dairy goat farm in Japan. Small Ruminant Research, 99(1), 65-71. doi: 10. 1016/j.smallrumres.2011.03.051

Leitner, G., Krifucks, O., Weisblit, L., Lavi, Y., Bernstein, S., \& Merin, U. (2010). The effect of caprine arthritis encephalitis virus infection on production in goats. The Veterinary Journal, 183(3), 328-331. doi: 10.1016/j.tvjl.2008.12.001

Lopes, F. C., Paiva, K. A. R. de, Coelho, W. A. C., Nunes, F. V. A., Silva, J. B. da, Escóssia, C. D. G. M. da,... Batista, J. S. (2016). Lactation curve and milk quality of goats experimentally infected with Trypanosoma vivax. Experimental Parasitology, 167(1), 17-24. doi: 10.1016/j. exppara.2016.04.006
Lucey, J. A., Otter, D., \& Horne, D. S. (2017). A 100-year review: progress on the chemistry of milk and its components. Journal of Dairy Science, 100(12), 99169932. doi: 10.3168/jds.2017-13250

Martínez-Navalón, B., Peris, C., Gómez, E. A., Peris, B., Roche, M. L., Caballero, C.,... Berriatua, E. (2013). Quantitative estimation of the impact of caprine arthritis encephalitis virus infection on milk production by dairy goats. The Veterinary Journal, 197(2), 311-317. doi: 10.1016/j.tvjl.2012.12.020

Melo, A. L. P. D., Torres, R. D. A., Ribeiro, J. I., Jr., Silva, F. F., Rodrigues, M. T., Silva, F. G. D., \& Brito, L. F. (2011). Identificação e modelagem da autocorrelação residual no ajuste do modelo de Wood às curvas de lactação de cabras. Ciência Rural, 41(10), 1818-1822. doi: 10.1590/S010384782011001000024

Michiels, R., Van Mael, E., Quinet, C., Welby, S., Cay, A. B., \& De Regge, N. (2018). Seroprevalence and risk factors related to small ruminant lentivirus infections in Belgian sheep and goats. Preventive Veterinary Medicine, 151, 13-20. doi: 10. 1016/j.prevetmed.2017.12.014

National Research Council (2007). Nutrient requirements of small ruminants: sheep, goats, cervids, and new world camelids.

Nord, K., \& Ådnøy, T. (1997). Effects of infection by caprine arthritis-encephalitis virus on milk production of goats. Journal of Dairy Science, 80(10), 2391-2397. doi: 10.3168/ jds.S0022-0302(97)76190-3

Pinheiro, J., \& Bates, D. (2006). Mixed-effects models in $S$ and S-PLUS. New York: Springer Science \& Business Media. 
Piva, M. M., Schwertz, C. I., Henker, L. C., Millán, Y., Mulas, J. M. D. L., Stedille, F. A.,... Casagrande, R. A. (2017). Metastatic mammary carcinoma in a cow. Ciência Rural, 47(7), 1-4. doi: 10.1590/0103-84 $78 \mathrm{cr} 20160736$

Rodrigues, A. S., Pinheiro, R. R., Brito, R., Andrioli, A., Oliveira, L., Sider, L. H.,... Teixeira, M. (2018). Avaliação de um controle estratégico da artrite encefalite caprina em rebanho caprino leiteiro. Sobral: EMBRAPA Caprinos e Ovinos.

Schultz, E. B., Silva, F. F., Garcia, A. O., Oliveira, H. R., Rodrigues, M. T., \& Brito, L. F. (2020). Genetic parameter estimates for caprine arthritis encephalitis in dairy goats. Journal of Dairy Science, 103(7), 64076411. doi: 10.3168/jds.2019-17740

Silva, E. M. N., Assis Silva, G. de, Souza, B. B. de, Alcântara, M. D. B. de, \& Carvalho, M. D. G. X. de. (2019). Influência da fase de lactação e do intervalo entre as ordenhas sobre a composição e produção de leite de cabras no semiárido. Revista Brasileira de Ciência Veterinária, 26(3), 99-103. doi: 10.4322/rbcv.2019.018

Siqueira, O. H. G. B. D., Mota, R. R., Oliveira, H. R., Duarte, D. A. S., Glória, L. S., Rodrigues, M. T., \& Silva, F. F. (2017). Genetic evaluation of lactation persistency and total milk yield in dairy goats. Livestock Research for Rural Development, 29(1), 142. doi: 10.4322/rbcv.2019.018

Sousa, M. M. de, Andrioli, A., Pinheiro, R. R., Alves, F. S. F., Santos, V. W. S. dos, Damasceno, E. M.,... Silva Vieira, L. da. (2019). An epidemiological study of caprine arthritis encephalitis virus (CAEV) in breeder goats from Northeastern Brazil. Semina: Ciências Agrárias, 40(5), 1857-1866. doi: 10.5433/16 79-0359.2019v40n5p1857

Souza, K. C., Pinheiro, R. R., Santos, D. O., Brito, R. L. L. de, Souza Rodrigues, A. de, Sider, L. H.,... Andrioli, A. (2013). Transmission of the caprine arthritis-encephalitis virus through artificial insemination. Small Ruminant Research, 109(2-3), 193-198. doi: 10.1016/j.smallrumres.2012.07.031

Tabet, E., Hosri, C., \& Abi-Rizk, A. (2015). Caprine arthritis encephalitis virus: prevalence and risk factors in Lebanon. Revue Scientifique et Technique, 34(1), 915-921.

Turin, L., Pisoni, G., Giannino, M. L., Antonini, M., Rosati, S., Ruffo, G., \& Moroni, P. (2005). Correlation between milk parameters in CAEV seropositive and negative primiparous goats during an eradication program in Italian farm. Small Ruminant Research, 57(1), 73-79. doi: 10.1016/j. smallrumres.2004.06.0 18

Venturino, E., Collino, S., Ferreri, L., Bertolotti, L., Rosati, S., \& Giacobini, M. (2019). An effective management strategy for the control of two lentiviruses in goat breedings. Journal of Theoretical Biology, 469(1), 96-106. doi: 10.1016/j. jtbi.2019.02.018

Wood, P. D. P. (1967). Algebraic model of the lactation curve in cattle. Nature, 216(5111), 164-165. doi: 10.1038/216164a0 